\title{
EsPíRITO, LIBERDADE E MístiCA EM Nicolas BeRdiaeV e na Mística Feminina CRISTÃ Medieval
}

\author{
SPIRIT, FREEDOM AND MYSTIC IN NICOLAS BERDIAEV ANDI
}

in the Medieval ChRIStian fEMALE MYSTIC

MARIA JosÉ CALDEIRA do AMARAL ${ }^{(*)}$

\begin{abstract}
RESUMO
Neste artigo vamos desenvolver "um diálogo" entre espírito, mística e liberdade com base nos conceitos de Nicolas Berdiaev e nos relatos de Mechthild von Magdeburg e Marguerite Porete. O objetivo essencial é uma aproximação do sentido da mística da liberdade constituído no pensamento filosófico de Berdiaev e a expressão na mística feminina medieval cristã, na tentativa de apontar para o caráter supra confessional da experiência mística. A articulação das concepções filosóficas de Berdiaev e a hermenêutica de relatos das experiências de Deus nos quais a alma experimenta a verdadeira liberdade, na linguagem de Mechthild e, torna-se nada, na linguagem de Marguerite, sustentam os limiares de sentidos da espiritualidade humana e seus desdobramentos na perspectiva da experiência cristã. A consideração principal, nesse diálogo, é sustentar a dinâmica espiritual do conceito de liberdade a partir de alguns fragmentos da vida e obra dessas mulheres místicas medievais em consonância com o teor dos argumentos de Berdiaev, que desconstrói, assim como elas, o dualismo ontológico entre a alma humana e Deus, postulado pela teologia tradicional.
\end{abstract}

PalaVras Chave: Nicolas Berdiaev. Mechthild von Magdeburg. Marguerite Porete. Lliberdade. Mística.

\begin{abstract}
In this article we will be developing a dialogue between spirit, mystic and freedom in Nicolas Berdiav, Mechthild von Magdeburg and MargueritePorete concepts.The essential intent is suggest an approach dealing with the sense of the mystic freedom within Berdiaev's philosophical thought and the expression of Medieval Christian Female Mystic in an attempt to point these concepts far removed from an exclusively confessional character of mystic experience. The Berdiaev's philosophical conception and the account of the hermeneutics of the experience of God that the soul experiences through the genuine freedom in Mechthild's language and where the same soul becomes nothing for Marguerite's language, both support the course's entrances of the human spirituality meanings and the its signification coming from a Christian perspective. The prime reason to consider this dialogue is to investigate the concept of freedom present in spiritual dynamic, from these medieval women's life and their literary production, that agree with Berdiaev's attempt to distance herself from onthological dualism between the human soul and God, postulated by traditional theology.
\end{abstract}

KEYWORDS: Nicolas Berdiaev. Mechthild von Magdeburg. Marguerite Porete. Freedom. Mystic.

${ }^{*}$ Psicóloga Clínica, Mestre e Doutora em Ciências da Religião CRE/PUC/SP. Pesquisadora do NEMES Núcleo de Estudos em Mística e Santidade/CRE/PUC/SP. Autora do livro "Imagens de Plenitude na Simbologia do Cântico dos Cânticos, Educ/FAPESP/Sp, 2008 e "Eros e Agape- Minne: Amar e Desejar Deus na Luz Fluente da Deidade de Mechthild de Magdeburg", São Paulo, Ed. Reflexão, 2014. Email: zezeamaral@uol.com.br 
Eu disse, diz Amor, que eles devem tomar cuidado, pois isso é necessário se querem chegar e alcançar o melhor. Essa vida é serva mesquinha que prepara o abrigo para a chegada do grande estado da Liberdade do Nada Querer, pelo qual a Alma é satisfeita em todos os pontos, ou seja, por esse nada que dá tudo. (Marguerite Porete)

Neste artigo vamos abordar a noção de conhecimento como atividade autêntica do espírito em liberdade no pensamento de Nicolas Berdiaev ${ }^{1}$, especialmente em sua obra traduzida para o francês e revisada por Olivier Clément: EspritetLiberté. A Filosofia, em Berdiaev, é determinada pela estrutura do espírito, por sua qualidade de constituir-se como epistemede si mesmo, qualidade essa frequentemente interditada pela invisibilidade do triunfo da experiência humana portadora do Eros divino submerso na barbárie, na rudeza e na decadência moral.

$\mathrm{O}$ atravessamento desse abismo torturante e trágico corresponde, aqui, à impossibilidade do conhecimento em alcançar qualquer solução dada pela crítica, pela história ou pela metafísica abstrata; esse atravessamento imprime e sustenta uma distância abismal entre Criador e criatura em medidas iguais. E é nessa mesma medida que a experiência mística torna-se, nas palavras desse pensador religioso, o triunfo sobre a condição de criatura (kreaturlichkeit): realidade exposta da mais íntima, pura e mesma condição da humanidade fragmentada na experiência religiosa cristã que definha e enfraquece enquanto o espírito e a liberdade se destacam no processo de retorno à realidade última do mistério. Esse mistério, essa perspectiva mistagógica, aponta para um

\footnotetext{
${ }^{1}$ Nicolas Berdiaeff (1874-1948), filósofo, russo, exilado em 1922 pelo governo soviético, vai para a França e estabelece-se em Paris-Clamart a partir de 1924. Depois de ter combatido o regime czarista, tenta, em vão, uma síntese entre o idealismo de Kant e um humanismo marxista, militando em círculos revolucionários e socialistas, enfrentando a prisão e o exílio (Vologda e Zitomir). Fiel à liberdade de Espírito e ao Cristianismo se opôs ao Bolchevismo e à Revolução de Outubro de1917. Sua filosofia religiosa, existencialista e personalista, dominada por sua paixão pela liberdade e sua fé no ato criador de todo ser humano, animada por um misticismo profético, orientada por uma nova época do Espírito, fará dele um dos pensadores mais marcantes do século XX. ( GAGNEBIN, 1994). Ver também o Prefácio de Jean-Claude Marcadé (BERDIAEV, 1985, pp. 7-14): "[...] Berdiaev, com virulência, denuncia os frutos do humanismo cristão-pagão da Renascença, esse humanismo que destrói a imagem e a semelhança de Deus no homem ao criar novos ídolos: o racionalismo do Iluminismo, a Revolução, o positivismo, o capitalismo, o socialismo, o anarquismo, (nós acrescentamos hoje, o comunismo e o nazismo), todas as ramificações distantes <do espírito de afirmação de si humanista>, isto é, a necrose do espírito criador autêntico do início da Renascença e das fontes onto-teológicas da vida [...]”.
} 
extrato insolúvel e persistente capaz de absorver, constatar e libertar o constrangimento causado pelo pretenso conhecimento objetivado pela razão diante do colapso irreversível e final dessa mesma razão entorpecida e absorta por sua e mesma falibilidade.

De acordo com Laurent Gagnebin (1994, pp. 7-13) compreender o pensamento de Berdiaev nesse interdito filosófico pode ser desconcertante para o leitor assegurado pela possibilidade da existência de um pensamento filosófico puro, pois, para ele, a filosofia é um ato de vida, afirmação radical de sua coerência máxima a partir da qual "não existe filosofia autêntica e verdadeira para além da vida e do mundo". Para Olivier Clement, um dos principais comentadores de Berdiaev e é quem prefacia EspritetLiberté, Berdiaev é, fundamentalmente, um revoltado - sufocado no mundo objetivo, onde prevalece e reina a separação, a violência e a opacidade; Clement acrescenta a essa qualidade atribuída: “Os revoltados procuram o 'Deus divino' 2 - para retomar uma expressão de Nietzsche - contra as caricaturas de Deus, caricaturas sociais ou cósmicas, a Ordem, o Poder, um Todo Poderoso, exterior que nega a liberdade." (BERDIAEV, 1984, p.12)

Berdiaev toma a experiência mística de Mestre Eckhart, Angelo Silesius, Jacob Boehme, dentre outros, assim como a teologia mística na antropologia de Gregório de Nissa e na cosmologia de Máximo, o Confessor e, ainda, desenvolve seus fundamentos em autores como Dostoiévski, Léon Bloy, Wladimir Soloiev, e sua filosofia, continua Olivier, não é um questionamento racional: "Ela parte da experiência espiritual para iluminar a existência plena que se aparenta à teologia mística, mas inscrita dentro de uma espiritualidade criadora, profética que busca decifrar e transfigurar a história” (BERDIAEV, 1984, p. 11)

O objetivo aqui, neste ensaio, é dialogar, a partir desses conceitos de Nicolas Berdiaev - Espírito e Liberdade - com a mística cristã medieval, especialmente com a mística feminina, século XII e XIII. Nesse diálogo, faremos algumas aproximações do sentido da liberdade desenvolvido nas duas obras de duas mulheres místicas medievais, consideradas beguinas: no Le miroir dês âmes simples et anéanties et qui seulement demeurent en vouloir et désir d'amour de Marguerite Porete3 e no Das Flie Bende Licht der Gottheit de Mechthild de Magdeburg4.

\footnotetext{
${ }^{2} \mathrm{O}$ termo em alemão que pode ser traduzido para o português como "Deus Deidade” para a mística alemã, ou a mística renana é Gottheit.
} 
As beguinas foram mulheres que viveram nos séculos XII e XIII, época de crise, caos, guerras, disputas, a partir das quais, o espiritual e intelectual eram invocados nos monastérios e universidades. Neste ambiente, belicoso e caótico, essas mulheres viveram em comunidades ou em grupos, submetidas ou não aos orientadores espirituais das ordens religiosas vigentes. Dedicaram suas vidas de forma apostólica e esse movimento veio a se estender por toda Europa: França, Holanda, Itália, Vale do Reno, Baviera. Segundo o Concílio de Viena, em 1311/12, esse modo de vida deveria ser proibido definitivamente e excluído da Igreja de Deus. Elegeram como mestras Marta e Maria em uma atitude devocional de ação e contemplação. O trabalho intelectual dessas mulheres tem sido estudado por pesquisadores contemporâneos de maneira incisiva5. Mechthild de Magdeburg e Marguerite Porete integram um grupo de mulheres beguinas cujos escritos suplantam algumas características comuns, dentre elas: a presença da experiência carnal e espiritual no caminho para a experiência de união com Deus. Eros e ágape regem a união da alma com Deus e os relatos dessa união, no âmbito das beguinas, se sustentam com a influência da tradição monástica cistercience, a partir da interpretação literal e antropomórfica da

3Marguerite Porete, beguina francesa de Hainault, valenciana, morta pela Inquisição em 01/o6/1310, em Paris, escreve o "Le miroir des âmes simples et anéanties et qui seulement demeurent em vouloir et désir d'amour" - "O espelho das almas simples e aniquiladas e que permanecem somente na vontade e no desejo do Amor”. Não há registros sobre sua história de vida. O diálogo entre o amor, a alma e arazão constrói o movimento central da linguagem do Le miroir. O amor (Amour)e a alma (L'âme) podem ser identificados como os autores do livro que são também Deus, e, o amor (Amour) é, ainda, a força dentro da alma responsável pelo aniquilamento da alma e de Deus. A razão aparece como a principal opositora ao amor com a qual a alma entra em duelo para que ela (a razão) seja vencida no processo de aniquilamento, ainda que Marguerite descreva a paradoxal participação da razão na descrição da ação transformadora no $L e$ miroir. As almas simples e nadificadas são aquelas que ultrapassam as próprias virtudes e a própria razão no movimento de desprendimentoe aniquilamento total, pois é no lugar desta nadificação que se encontra o espelho que reflete Deus.

4 O Livro de Mechthild de Magdeburg é tudo que possuímos para apreender o pouco que se sabe de sua vida. O Das FlieBendeLicht der Gottheit - A Luz que flui da deidade - é a única fonte capaz de fornecer dados biográficos de Mechthild. Sua obra revelada por Deus foi escrita em primeira pessoa e em língua vernacular. Mechthild de Magdeburg nasce em 1207 nas proximidades de Magdeburg. Em 1282 ela morre.Em 1230, ela deixa a casa dos pais, com 23 anos, para viver em Magdeburg, como beguina. Em 1250, começa escrever. Escreve do livro I ao livro V até 1259. Em 1260, fica doente e, possivelmente, passa um período na casa dos pais. Em 1270/71, o livro VI estava pronto. Em 1270 Mechthild entra para o convento de Helfa. Entre 1270 e 1282, ela escreve o livro VII. Na mística de Mechthild, a linguagem aponta para uma potência de eros no corpo do próprio texto, e os livros dessas mulheres místicas medievais se valeram de eros para que a alma se fizesse convertida e conhecesse ágape - o verdadeiro amor de Deus. Existe uma tensão no texto entre essas duas potências conceituais formalizadas pelos gregos e desdobradas, ao longo dos primeiros séculos da era cristã, no desenvolvimento das experiências místicas.

5 Esta forma de vida religiosa, extra-claustro e semi-religiosa, teve sua origem nos países de língua germânica, no vale do Reno, como é o caso de Hadewijch de Amberes, Beatriz de Nazareth e Mechthild de Magdeburg, no século XI e XII; Ângela de Foligno, no final do século XIII, e Catarina de Siena, no séc. XIV, na Itália; na França, Margarida de Oingt (Lyon) e Marguerite Porete (Valência); na Inglaterra (séc. XV), Juliana de Norwich.; Guilherma de Bohemia que viveu em Milão em 1260, como beguina. (Ver CIRLOT; GARÍ, 1999, pp. 12-5). 
linguagem bíblica, principalmente do Cântico dos Cânticos, iniciada por Orígenes e continuada na Idade Média por São Bernardo de Claraval.

O fino amor, o amor cortês, o desejo, a distância, a falta, a loucura, o amor violento, o amor insano, o verdadeiro Amor, o aniquilamento estão lavradosna linguagem da experiência do amor de Deus na alma. Uma linguagem muito distante da linguagem scholar da época, mas que a contém em si mesma. McGinn (2003, V. III, p.228) ${ }^{6}$ aponta uma diferença importante em relação a essas influências: tanto os autores da escola monástica do século XII, quanto as mulheres místicas do século XIII, estavam convencidos de que o verdadeiro amor de Deus envolvia o sentido de violência e veemência, como a violentia caritas de Ricardo de São Vítor, por exemplo; mas a linguagem das mulheres religiosas ultrapassava a linguagem masculina na ênfase que era dada por elas no efeito devastador da loucura de amor. O amor esponsal entre Deus e a alma, para elas, não era somente o amor de uma alma finita direcionada a algo infinito; o amor mútuo (amor mutuus) presente na teologia da mística monástica é o amor esponsal entre Deus e o homem no qual está o mais pleno e mais elevado de todos os afetos (affectus). Mechthild e Marguerite, dentre outras, descrevem essa mutualidade como contínua e verdadeiramente única: uma união de profundidade abissal na qual a alma torna-se completamente equalizada ao Amado e ao Amante Infinito.

\section{APROXIMAÇÕES}

Numa primeira aproximação às ideias de Berdiaev, a experiência mística, ao contrário do que se postula, supõe uma vitória sobre o abismo da transcendência e sua exterioridade, ou seja, não é a transcendência da divindade que caracteriza o ápice da vida espiritual, mas a Sua imanência vívida e direta, o real sentido configurado na experiência cristã. E é assim que o atravessamento entre a identidade e o abismo, entre a criatura e o Criador podem existir em medidas iguais, o que, por si só justifica a linguagem paradoxal e antinômica dos textos medievais que abordam a experiência direta de Deus elaborada fora de qualquer dualismo ontológico constelado racionalmente entre desejo e amor, entre erose ágape. Esse é o triunfo sobre o estado de criatura, que é sustentado pela essência - o extrato - da vida mística - do qual falávamos acima e no qual encontramos

[...] a definição mais profunda e mais intrínseca de sua natureza. Dentro da experiência mística não há mais um dualismo insuperável se opondo entre o

\footnotetext{
${ }^{6}$ Ver também McGINN, 2003, V. I, e V. III e VAUCHEZ, 1999 entre outros.
} 
natural e o sobrenatural, o divino à criatura; nela o natural torna-se sobrenatural, a criatura se deifica. Mas a união perfeita com Deus não implica no desaparecimento do homem, nem na distinção de duas naturezas. Somente o nada vivido é vencido7 (BERDIAEV, 1984, p. 233)

A superação do nada vivido deve ser considerada como a base da experiência direta de Deus e como a fonte de seu movimento criador desvelado. Na perspectiva religiosa, a experiência mística torna-se o verdadeiro retorno ao último mistério do ser e a autêntica expressão, por seus fundamentos, da união entre o Espírito divino e o espírito humano, entre o Criador e a criação, e é assim que Nicolas Berdiaev consagra seu pensamento na tarefa de construir, comentar e criticar dois conceitos fundamentais: Espírito e Liberdade. Em EspritetLiberté, Berdiaev propõe uma filosofia da história profética subsidiada pela liberdade existencial autêntica - a liberdade incriada, original, primeira que é a filosofia do espírito. A partir daí o estudioso de mística desenvolve uma espécie de hermenêutica da profundidade, da originalidade, da realidade última e dialoga intensamente com a experiência religiosa humana, com santos e místicos, filósofos e pensadores.

Inicialmente, (a inserção de) um fragmento extraído da Luz fluente da deidade da beguina alemã Mechthild de Magdeburg sustenta uma dúvida e uma constatação ao mesmo tempo e, a título de uma espécie de epígrafe reflexiva, o leitor poderá recorrer a ela, em vários momentos do texto que se segue: "Como pode, Senhor, sua bondade ser do tamanho de minha miséria?” [MM, VII, 6]8

\footnotetext{
7 Para Berdiaev, a mística é a via de deificação, na linguagem da ortodoxia cristã, a theose do homem e do mundo e, sobre esse ponto de vista, todos os místicos, de todas as épocas e de todas as confissões religiosas estão de acordo. Vamos nos abster, aqui, do desenvolvimento dos conceitos da mística ortodoxa cristã em sua objetividade. Para uma melhor compreensão das diferenças, colocadas pelo próprio autor, em relação ao desenvolvimento da linguagem e conceitos pertinentes à pesquisa da mística cristã em geral, conferir o capítulo 7: A Mística e a via Espiritual, (BERDIAEV, 1984, pp. 229-54) onde Berdiaev, pensador ortodoxo, além de apontar para as características e diferenças principais entre a mística católica e a mística ortodoxa,aponta também para duas questões fundamentais: a primeira é o fato de que a mística profética, a mística do Espírito Santo nasce no plano espiritual da ortodoxia russa e é inerente ao povo russo, mas, para ele, essa mística existiu igualmente no Ocidente, na idade média, na época da Reforma e em alguns segmentos individuais. Maistre Eckhart é um dos representantes maiores ao lado de Tauler, Suso, Ruysbroeck, AngelusSilesius no âmbito da mística alemã. Nesse campo de pesquisa, sem dúvida, a mística medieval vem sendo discutida a partir de seus principais fundamentos tanto na mística ortodoxa, na mística latina e na mística alemã ( p. 241- 47). A segunda questão é a de que, para Berdiaev, independente de toda santidade, existem e existiram homens e mulheres que abraçaram um sentimento diante do profundo mistério que envolve a vida e que aponta para a existência de uma mística inerente à natureza humana; é por essa razão que na história da vida e da cultura espiritual da humanidade encontram-se experiências, relatos e obras que não se definem a partir de uma disciplina ou de uma via particular; para Berdiaev, Dostoïevski era um místico por seu sentimento e sua compreensão da vida, pelo caráter de sua criação, assim como outros pensadores que dedicaram suas vidas e obras ao mesmo sentido místico profético, dentre eles, Baader, Joseph de Maistre, Soloviev, Leon Bloy.
}

8 As traduções do alemão são livres e as citações estão como no original MAGDEBURG, Mechthild von. Das flieBende Licht der Gottheit:Nach der Einsiedler Handschrift in Kritischem Vergleich mit der gesamten Überlieferung. München: Hans Neumann; Zürich: Artemis-Verlag, 1990, indicadas com as iniciais da autora, Mechthild Von Magdeburg, seguidas do capítulo em romano e o versículo em cardinal. 
(MAgdeburg, 1990) Inicialmente, a inserção de um fragmento extraído da Luz fluente da deidade da beguina alemã Mechthild de Magdeburg sustenta uma dúvida e uma constatação ao mesmo tempo e, a título de uma espécie de epígrafe reflexiva, o leitor poderá recorrer a ela, em vários momentos do texto que se segue: "Como pode, Senhor, sua bondade ser do tamanho de minha miséria?” [MM, VII, 6]9 (MAGDEbURG, 1990)

Em Mechthild, ainda que pareça mesmo tratar-se de uma descoberta, a linguagem mística está constelando o sentido desse artigo: há uma equalização do amor divino à miséria humana como uma hipótese incompreensível, porém fundamental e verdadeira. De acordo com ela, o fim do amor humano é também o que lhe causa- o amor é causa de si mesmo. Deus era, ao mesmo tempo, o que ela desejava e o que fazia com que ela o desejasse. Deus mesmo mostrava isso a ela, pois o amor a Deus, experimentado por ela, tinha a participação dele mesmo e então, a natureza do amor estava na dileção (diligere) natural que oágape opera e consuma na alma humana. Dito de ouro modo, o fato de que Mechthild amava a Deus mais do que a si mesma é desejo de Deus mesmo. A obra da mística alemã não foi construída à margem da invisibilidade do triunfo da experiência humana portadora do Eros divino submerso na "sua miséria", como ela mesma disse. Mas a experiência da alma de Mechthild conhece essa distância abismal entre Criador e criatura em medidas iguais.

A existência plena, a saber, a vida propriamente como ela é, se constrói na proporcionalidade dessa indagação de Mechthild a Deus, a indagação que contém em si mesma uma constatação, individual, íntima e é reflexo de uma situação real da vida e do mundo e que combina com o que Berdiaev fala sobre a experiência de Deus. Para ele, a experiência mística é íntima e fechada, mas não é individualista, sendo uma das dimensões da espiritualidade e, em sua profundidade é o vértice, o âmago da vida espiritual. (BERDIAEv, 1984, p. 230) Mas, voltando à constatação de Mechthild, essa miséria, provavelmente composta de fealdade, rudeza moral, decrepitude, pecado, coincide com a bondade, o amor de Deus, graça pura, justamente no limite entre imanência e transcendência, redução máxima no pensamento moderno, mas, com a exigência de que essa redução seja, no continente extremo da expressão da

9 As traduções do alemão são livres e as citações estão como no original MAGDEBURG, Mechthild von. Das flieBende Licht der Gottheit:Nach der Einsiedler Handschrift in Kritischem Vergleich mit der gesamten Überlieferung. München: Hans Neumann; Zürich: Artemis-Verlag, 1990, indicadas com as iniciais da autora, Mechthild von Magdeburg, seguidas do capítulo em romano e o versículo em cardinal. 
degradação humana, o ganho máximo do fim último da vida humana: a ultrapassagem do estado de criatura. O que continua existindo é o que não podemos negar nem apagar do vivido, de maneira transfigurada. Nos resíduos, nos restos do sofrimento vivido e na dor da qual eclode a consciência humana de sua condição amoral, desconhecida, indeterminada e natural é que reside a possibilidade da transfiguração e da certitude do sentido profético no pensamento de Berdiaev. Esse pensamento está articulado no fato de que o homem experimenta sua realidade submetendo-se a realidades externas e objetivadas, o que o leva ao constrangimento incessante no qual estão postas a crença e a luta - ambas inócuas - nos condicionamentos da natureza e seus desdobramentos na vida, no mundo e na história. O ser humano, diante de sua inconsistência, sua falsa liberdade, se dissolve nessa condição e, na grande maioria das vezes, inconsciente desse constrangimento existencial e espiritual, sintetiza a mentira contínua sobre si mesmo, sobre sua história e sobre seu mundo. Essa existência nula que se anula e se destrói a um só tempo são os trunfos, de um ser humano falsamente divinizado e da ideia de um Deus bestial: cacife do niilismo, como bem disse Olivier Clement (BERDIAEV, 1984, p. 13).

Berdiaev vai dizer: "Todas as forças do meu espírito, de minha consciência são orientadas pela penetração absoluta dos problemas que me torturam" (BERDIAEV, 1984, p.24). A problemática torturante do Espírito é a proposta epistêmica que se debate com a impossibilidade da solução pela razão crítica ou histórica e mesmo pela metafísica abstrata de Deus. A dinâmica da Liberdade é a obediência à vontade de Deus, que espera do homem outra coisa e muito mais do que aquilo que se entende habitualmente falando de Sua vontade.

No espelho das almas simples e nadificadas e que permanecem no desejo do Amor, Marguerite Porete ${ }^{10}$ traz a mesma crítica de Berdiaev, e com ela vamos introduzir a questão da liberdade. Disse ela:

Na realidade, quem fala de Deus a toda hora, com quem quer e onde quer, deve saber, sem nenhuma dúvida, que jamais sentiu o coração verdadeiro do amor divino, pois esse apreende a alma em meio a todos sem que ela perceba. $\mathrm{Na}$ realidade, o coração verdadeiro e sofisticado do amor divino é sem matéria de criatura [...]; e essas almas têm o hábito de tudo compreender e tudo esquecer devido à sutileza de seu amante. (PORETE, 2008, p.72-4).

\footnotetext{
${ }^{10}$ A edição utilizada nesse artigo é a tradução para o Português de Sílvia Schwartz: PORETE, Marguerite, O espelho das almas simples e aniquiladas e que permanecem somente na vontade e no desejo do Amor. Petrópolis, Vozes, 2008
} 
Para Berdiaev o mundo criado pode ser deificado, mas essa deificação não pode ser, senão obra da graça e da Liberdade (BERDIAEV, 1984, p. 244) e esse abismo existente entre aqueles com matéria e com criatura e essa deificação é, em si mesmo, para a vida mística, uma segurança. Para as almas nadificadas e simples, o amor de Deus é sutil porque ele não é pessoal, portanto, sendo impessoal, ele é a realidade da deidade mesma (Gottheit). No Le Miroir de Marguerite Porete, esse estado sem matéria, sem criatura, sem vontade é extensamente discutido entre a alma, a razão, o amor e alma libertada. No capítulo 12 denominado "O verdadeiro entendimento sobre o que esse livro diz em tantos lugares, que a Alma Aniquilada não tem mais vontade”, Marguerite escreve o diálogo entre o Amor, o Entendimento da Razão, a Razão e o Entendimento do Amor: o entendimento do Le Miroir de que a Alma aniquilada não tem mais vontade, nem é capaz de tê-la, nem de querer tê-la, e que com isso a vontade divina é perfeitamente realizada (PoRETE, 2008, p.51) é o argumento do Amor que diz ainda "[...] que a alma não tem o suficiente do amor divino, nem o Amor divino tem o suficiente na Alma, até que a alma esteja em Deus e Deus na Alma, dele e por ele colocada, em tal estado de repouso divino. Então, a Alma tem toda satisfação." (PoreTe, 2008, p.50) E, "Sua Alteza”, o "Entendimento do Amor" explica ao "Entendimento da Razão" que a alma aniquilada e, portanto, livre, também chamada de alma liberada, quer a vontade de Deus e quanto mais a alma a quer mais ela continua querendo, mas esse querer ela não pode obter por conta de sua pequenez de criatura: "Mas Deus quer que ela a queira e que ela tenha essa vontade, e tal vontade é a vontade divina, que dá esse estado à criatura livre. Essa vontade divina, que Deus a faz querer, corre através dela no fluxo da compreensão divina, no âmago do amor divino [...]"(PoreTE, 2008, p. 51). E é por isso que a alma livre não tem vontade, isto é, a "Compreensão Clara" sabe que há um estado, entre todos, - o mais nobre de todos os estados -que a criatura não pode alcançar, senão por meio do nada querer. Nesse capítulo, Marguerite conclui que o que a Razão não pode entender é que a alma liberada permanece insatisfeita e em que consiste essa insatisfação:

É por querer a vontade divina, pois quanto mais a queremos menos satisfação encontramos nela. Contudo, essa mesma vontade é a vontade somente de Deus e a glória da Alma, pois o Entendimento do Amor Divino, que permanece e está na Alma aniquilada e liberada, o entende bem, e sem hesitação, pois ela mesma é isso. (Porete, 2008, p. 50). 
A "Compreensão Clara," na linguagem de Porete, aponta para o nada criado que não aniquila e o nada incriado na alma liberta, a qual só é livre para o entendimento do amor divino, por meio do nada querer, ou seja, da vontade de Deus; em outras palavras, o nada incriado da alma liberta de Marguerite consagra o sentido da liberdade de Berdiaev, e coincide com "o nada querer" da alma, que abriga a vontade de Deus somente. Uma filosofia religiosa pautada pela intensidade da razão vencida por si mesma nos moldes de uma teologia negativa sustenta

[...] a possibilidade do conhecimento pelo paradoxo e pela antinomia. Em nossa confissão de caráter inacessível da divindade, na impossibilidade de um conhecimento racional da vida divina, há, igualmente, um conhecimento e uma filosofia religiosa. A teologia negativa é também um conhecimento de Deus. A afirmação dos limites da razão supõe sua acuidade e sua intensidade; a razão iluminada, mergulhada no espírito, conhece um grau supremo e não somente um aniquilamento. (BERDIAEV, 1984, p. 85).

Mesmo escapando às categorias da razão, no seu mistério, a liberdade é a vida e ela só é acessível dentro da própria experiência da vida. No campo do conhecimento Berdiaev vai dizer que a vida espiritual não é objeto de conhecimento, ela é, nela mesma, o conhecimento espiritual:

O espirito não é uma substância, não é uma realidade objetiva, [...] Uma metafísica racional do Espirito é impossível. A vida não se revela a não ser na experiência. O espirito é vida e não objeto e, por consequência, ele não pode ser conhecido a não ser dentro de uma experiência concreta, dentro de uma experiência espiritual, dentro do cumprimento do destino. No conhecimento do espírito, sujeito e objeto não se opõem um ao outro. O espírito que conhece é ao mesmo tempo conhecido. (BERDIAEV, 1984, p. 32).

É nessa ideia de claridade espelhada que a liberdade é equalizada ao espírito no sentido da existência de uma índole íntegra de onde se desdobra o fato de que o conhecimento supõe uma mística da liberdade, porque ela é um mistério - o mistério da profundidade infinita do espírito. Não é a graça que se opõe à liberdade, mas a necessidade. Graça, liberdade e espírito se opõem à necessidade, à coação e ao constrangimento. Por isso a mística da liberdade é uma forma de conhecimento no sentido de uma nova consciência de si, de Deus e da realidade: trata-se de uma consciência totalmente livre, despojada, interiorizada, acolhedora da graça.

Nesse sentido que nos é dado pelo pensador russo, a liberdade pressupõe um destino que nos obriga a compreender sua dialética trágica. Berdiaev postula a existência de duas liberdades, a saber: a primeira (incriada, original, o espírito propriamente dito) e a segunda (a necessidade, a vontade natural, os 
desígnios livres da natureza) e, ambas possuem uma dialética dramática dentro da qual elas se degeneram em seu contrário. A primeira liberdade, a liberdade inicial, irracional e insondável, não garante por ela mesma que o homem siga o caminho do bem, que a verdade triunfe em sua vida, que a liberdade final e suprema seja vitoriosa no mundo. As forças infinitas do bem e do mal se encontram em estado latente e revelam a possibilidade de atualizações mais variadas e opostas (BERDIAEV, 1984, p. 135).

A primeira liberdade não supõe necessariamente uma adesão à vida em verdade, à vida em Deus. Ela pode escolher a via da discórdia, do ódio, do rancor, da afirmação de uma parte do ser contra o outro, enfim o mal (BERDIAEV, 1984, pp. 136-137). Da mesma maneira, a segunda Liberdade, presa nela mesma, possui também seu destino inexorável, sua dialética interior inelutável (BERDIAEV, 1984, p. 136-137). A liberdade do espírito não é somente a liberdade de Deus, ela é, também, a liberdade do homem. A liberdade humana não é somente a liberdade em Deus, mas, também, a liberdade em relação a Deus. O homem deve ser livre em consideração a Deus, ao mundo e à sua própria natureza. A liberdade, no sentido da Verdade, não pode ser construída a partir da Verdade em si mesma, pois a liberdade é anterior à Verdade. E, ainda, a liberdade não pode ser identificada ao Bem ou à perfeição da vida que são, todavia, única e livremente afetados pela Verdade. É, justamente, no fato de que a vida e o Bem podem, ao mesmo tempo, serem acolhidos e afetados pela Verdade do Espírito em liberdade, que reside a fonte da dignidade e da originalidade qualitativas da vida espiritual, moral e religiosa.

O grande mistério da liberdade não se encontra aonde nós, geralmente, procuramos e, frequentemente estabelecemos. A liberdade do homem não constitui, de sua parte, uma reivindicação e uma pretensão. $O$ homem renuncia facilmente à liberdade em nome da sua tranquilidade e de sua felicidade. [...] Em seu destino individual e histórico, ele, constantemente, renuncia à liberdade e escolhe, preferencialmente, a quietude e a felicidade dentro de sua necessidade. [...] Deus exige do homem a liberdade do espírito; [...] O desígnio divino sobre o homem e sobre o mundo não pode incarnar-se sem a liberdade do homem, sem a liberdade do espírito. A liberdade humana tem, por fundamento, a exigência da vontade divina. (BERDIAEV, 1984, p. 132).

O Espírito, sendo a liberdade, não conhece o constrangimento das coisas objetivas nem as razões desse constrangimento, constrangimento esse promovido pela ação das duas liberdades atuando juntas em seu contrário (vergonha, miséria, vontade versus verdade, liberdade, amor) como, acima, indagava Mechthild de Magdeburg, em nossa epígrafe reflexiva. Para ela, a constatação da bondade de Deus equalizada à sua miséria só é encontrada no 
vazio total que se traduz ao nada, à liberdade, numa tentativa constelada em seu livro, "A Luz que flui da Deidade”, para configurar o amor de Deus, que ela mesma vivencia, na mística tardia medieval cristã: libertar-se de ser livre e tornar-se mais livre do que ser livre, subjugando a liberdade e vencendo os livres, o que antecipa, também, o Abgrund- o fundo sem fundo da alma de MestreEckhart:

Esse grunt(fundo) da alma que não faz senão um com o gruntde Deus e no qual se consome sua unidade com Deus pelo nascimento do Filho nele e pela presença nele da insondável Deidade ela mesma. Pois o justo nasce de Deus, ele é em verdade, quer dizer em seu fundo que é seu nada, idêntico ao filho de Deus, e a ação intradivina opera nele. Mas se, no homem Deus conhecesse Deus, o homem não conhece mais Deus, e nós caímos sobre o paradoxo [...] para se unir a Deus, o homem deve se perder, ele está unido a Deus quando ele não é mais: ele não está, pois, não mais unido a Deus. (BRUNNER in ZUM BRUNN; DE LIBERA 1984, p.215).

No terceiro livro de Mechthild, o deserto é uma metáfora profundamente religiosa e é uma expressão da condição da alma em ágape, aquela que ama o nada, é só e livre de todas as coisas.Por isso, a alma que ama o nada ultrapassa a liberdade, cuida dos doentes e liberta os presos; e não tem nada, nada lhe pertence, nem mesmo suas virtudes que devem ser queimadas com o fogo do amor e, assim, é possível beber da água do sofrimento e viver no verdadeiro deserto:

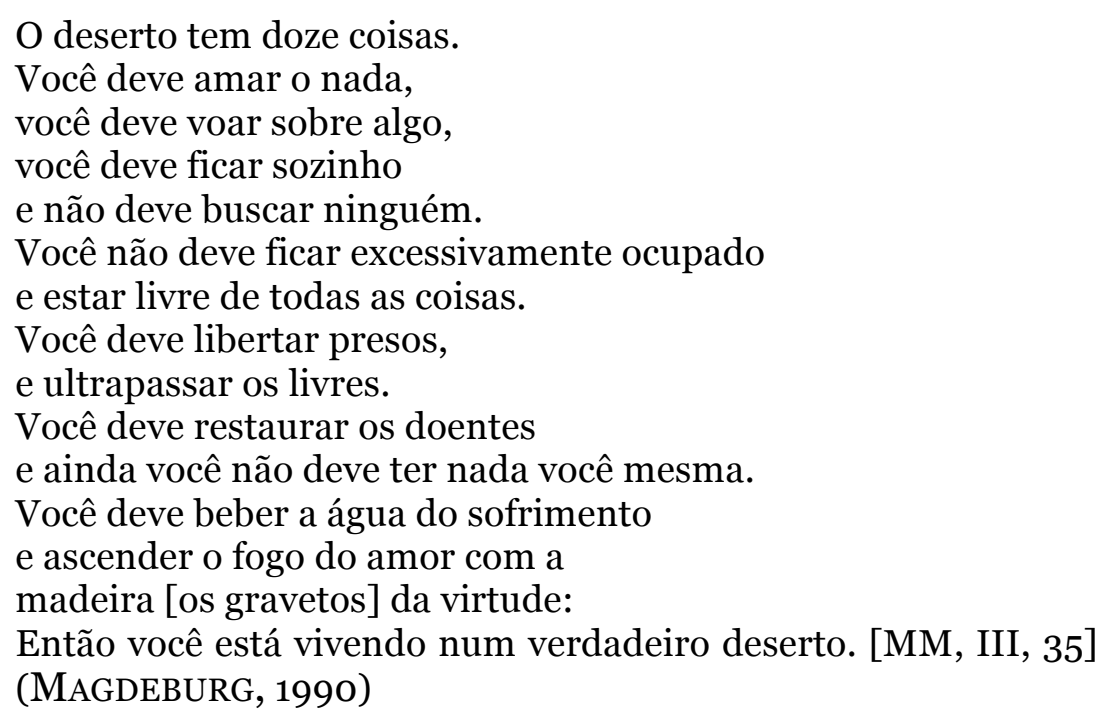

Para a beguina alemã, a alma amorosa que ama tudo que Deus ama possui um olho no qual Deus a ilumina. É nesse verdadeiro deserto que se encontra a liberdade da alma da qual estamos falando. Ela (a alma), sendo mais livre do que os livres, vê dentro da deidade eterna e vê como essa deidade tem trabalhado na alma com a sua natureza (de Deus). E Ele a formou como Ele mesmo, plantou-a em Si mesmo e se uniu a ela, mais do que a todas as criaturas. 
É dessa forma que Mechthild entra no debate sobre natureza e graça, pois a concepção trinitária do Pai, do Filho e do Espírito, em ação conjunta, é uma ação de um Deus invisível, do Qual não podemos falar, nem conceber.

Esse Deus invisível existia antes da própria criação; mas, onde estava Deus antes de ter criado qualquer coisa? Para Mechthild, Ele estava em Si mesmo e todas as coisas estavam tão presentes e tão manifestas para Ele como estão hoje. E como podemos dar forma a esse Deus invisível e inconcebível? Mechthild usa a imagem de uma esfera, em sua linguagem, para responder a essa pergunta: todas as coisas estavam dentro dessa esfera sem fechadura e sem porta. $\mathrm{Na}$ parte mais baixa dessa esfera está a fundação sem fundo, abaixo de todos os abismos, e a parte mais alta da esfera é um topo acima do qual não há nada. A circunferência dessa esfera é um círculo imensurável. Nesse ponto, Deus ainda não se tornou um criador. E, quando Deus criou todas as coisas, essa esfera não se abriu; ela se manteve inteira e manter-se-á inteira para sempre. Quando Deus se tornou criador, todas as criaturas se tornaram manifestas em si mesmas. E, depois de construir a imagem de Deus na esfera imensurável sem fundo e sem altura, ela diz:

Eu disse em uma passagem deste livro que a Deidade é por natureza meu pai. Você não entende isto, e diz: Tudo que Deus fez conosco é completamente uma questão de graça e não de natureza. Você está certo, mas eu estou certa também. Considere esta analogia. Não importa o quanto sejam bons os olhos de uma pessoa, ela não conseguirá enxergar além de uma légua. Não importa o quanto perspicaz a mente de uma pessoa seja, ela não conseguirá compreender coisas não-físicas exceto com fé, e ela procura como um homem cego na escuridão. A alma amorosaque ama tudo que Deus ama e odeia tudo que Deus odeia possui um olho que Deus a ilumina. Com ele, ela perscruta dentro da Deidade eterna e vê como a Deidade tem trabalhado na alma com sua natureza. Ele a formou de acordo com si mesmo. Ele plantou-a em si mesmo. Com ela, principalmente entre as criaturas, ele se uniu. [MM VI,31] (MAGDEBURG, 1990).

Ela se refere à natureza da alma e do corpo na deidade sem fim, sem começo, sem fundo e sem altura.A humanidade que se desfaz da humanidade e o Deus que se desfaz de sua Deidade contem, juntos e unidos à graça, a mesma natureza espiritual.

Essa é uma posição que Berdiaev (1984, p.130-6) discute extensivamente: natureza, graça, liberdade e necessidade. A partir da polêmica bem conhecida e discutida no cerne do Cristianismo, natureza e graça não se opõem. Como já vimos, essa oposição só existe entre graça e necessidade, contingência. A liberdade, para ele, precede, no homem, a ação da revelação e da graça. Se a natureza humana fosse definitivamente deformada e a liberdade do espírito 
fosse aniquilada, não existiria no ser humano uma disponibilidade capaz de receber e acolher a verdade da revelação e o ser humano seria, então, insensível à ação da graça. Mas o homem, ainda que doente e caído (no sentido mesmo da queda), é também um ser espiritual.A ação da graça supõe a liberdade do homem e ela se diferencia nela mesma do ato da criação do mundo. $O$ argumento de Berdiaev é decisivo:

O homem tem em si a imagem divina, ele é uma ideia divina, um desígnio divino, sem ser, contudo, divino por sua natureza [...]. A liberdade do homem supõe a possibilidade de sua divinização e a possibilidade de aniquilar nele mesmo a ideia e a imagem divinas. O homem privado da liberdade do mal não será mais que um autômato do bem. (BERDIAEV, 1984, p. 135)

Inalienável, a alma nadificada e livre é aquela que se encontra diante de seu destino inexorável, de sua condição naturalmente deificada e sensível à ação da graça. A liberdade incriada e espiritual coincide com o intento divino, em Marguerite e em Mechthild, a partir da experiência do Amor que permanece no Desejo e na certeza de que Deus é o mais justo dos amantes. Em Berdiaev o Espírito é a Liberdade e a vida espiritual é o nascimento, a eclosão da alma original.

\section{CONSIDERAÇÕES FINAIS}

A atividade autêntica da vida espiritual - a liberdade - postulada por Berdiaev como o triunfo da experiência humana portadora do Amor divino, foi enriquecida pelo aparecimento da alma simples e aniquilada que "não se importa com vergonha nem honra, com pobreza, nem com riqueza, com tranquilidade ou inquietude, nem com amor ou com ódio, nem com inferno ou paraíso [...]. Essa alma tem tudo e não tem nada, sabe tudo e não sabe nada" (Porete, 2008, p.52).

O efeito dessa superabundância da abertura arrebatadora torna a Alma tão livre, tão nobre e tão liberta de todas as coisas que, mesmo após o fechamento, ela não cai mais no estado anterior, onde se submetia á vontade. Embora o último estado seja guardado em Deus mesmo, para ser dado apenas na glória eterna, quando a alma tiver deixado o corpo, a experiência do êxtase místico permite, por um breve momento o gozo do Outro, o gozo dessa glorificação, onde tempo e eternidade se fundem como um istmo que vincula o Criado e o incriado. (DIAS, 2010, p. 209)

Na Luz que flui da deidade, Mechthild dispõe o eros e o ágape, na unidade mística de seus escritos, no lugar onde Deus, Alma e Amor coincidem. O amor que flui da luz de Deus é esse amor que não nasceu do pensamento humano; a única reparação e o único argumento que ele (o amor) possui em relação à alma é o de penetrar nela mesma para que, por meio dele, a alma seja empurrada, atraída e inserida em Deus. O amor rouba a alma dela mesma, ela morre e, 
morrendo, deixa-o viver em si mesma e torna-se, nela mesma, a constituição de sua própria anatomia.

Em Mechthild de Magdeburg é necessário que Deus nos liberte de todas as amarras, menos das amarras do amor (Minne) ${ }^{11}$. Para ela o conhecimento sem o fogo do amor é arrogância e hipocrisia, pois Deus a ama no quanto menos ela merece, mas ele a ama onde ela mais necessita, na sua miséria e na sua impossibilidade mesma de amar e de dizer sobre as coisas que ela vislumbra quando constata a Minne - a tradução equalizada de eros e ágape no único movimento da deidade única; a dádiva de Deus é a própria natureza divina na alma e, por isso, ela diz estar certa quando insiste que a graça divina é também uma questão de natureza. (AMARAL, 2008, p. 190)

A alma que se lança no abismo de Deus e no abismo de si mesma não é a alma escrava do seu desejo natural, mas sim, a alma que é livre para amar, ainda que ela permaneça sempre no desejo desse Amor, e é nesse Desejo que a liberdade espiritual se mantem acesa no fogo do Amor. A reivindicação da liberdade do espírito engendra necessariamente o drama e o sofrimento da vida. $\mathrm{O}$ homem espiritualmente livre se configura como desejo de Deus. O

${ }^{11} \mathrm{O}$ Glossário dos Sermões Alemães de Mestre Eckhart refere-se àMinne como a essência, ao âmago visceral de Deus, à deidade propriamente dita. Toda etimologia dessa palavra e todo seu parentesco grego e latinoMenos (sentido) no grego, Mimneskein (recordar-se), Memini(lembrar-se) no latim, Mens (mente) no latim, Monere(admoestar)estão relacionados com o sentido dado por São Boaventura ao vocábulo - Mens(-tis), nous, mente - que designa o nível mais alto de liberdade no ser humano, "o seu ápice, no e através do qual o ser humano é tocado por Deus e penetra para dentro de Deus".(ECKHART, 2006, p. 327). Como Mechthild o termo usado no alemão medieval por Eckhart para o amor (Liebe) é Minne. Nesse sentido, a palavra Minnesustenta o movimento visceral de Deus no ato puro e elevado, suspenso, disponível e vivo na alma humana. A raiz indo-germânica mensignifica pensar, no sentido de estar suspenso, solto, disposto na espera, vivo de coração. A Minne, como ato puro (actuspurus) é o ontologicumdo ente na sua totalidade do mundo medieval: A presença da pura e límpida doação total da Minneno todo, na totalidade do ente, do que é e pode ser, atua como imensidão, como profundidade, e como originariedade. Como imensidão Minneabraça e assume todos os entes, desde os supremos até os ínfimos, não deixando de fora nenhum ente, nem sequer o próprio nada. É a largueza da generosidade. Como profundidade, atravessa e impregna de cima a baixo todas as dimensões e ordenações do ente, de tal sorte que desce do céu até o inferno, subsume, suporta, faz seus todos os altos e todos os abismos, todas as positividades e todas as negatividades do ente, penetra nos seus mais obscuros e ocultos recantos da maldade, para ali buscar, por mínimos que sejam, vestígios de igualdade com o seu ser-Minne, nos fundos de mais variegados níveis da intensidade de ser. Como originariedade, Minne é como que o in-stante do ponto de salto de todo ente, isto é, de cada ente, cada vez na novidade da primeira e última chance da possibilidade da acolhida do ser, oferecendo-se sempre nova e de novo, como fonte, livre e solta na gratuidade da geração do ente, fazendo-o sua cria, seu filho, como a refundação de si, sem mais nem menos, na igualdade de condição (nota14, p.345).

Ver também o sentido da Minne medieval na mística feminina em (AMARAL, 2014, p. 104-106 e p.139-163). 
aniquilamento da alma liberta a liberdade e sua face exposta desestabiliza os argumentos da razão natural transformando-os numa nova consciência que é a consciência permanente, ou seja, o que permanece é a essência - o extrato - da primazia do espírito que cumpre o seu destino.

\section{REFERÊNCIAS}

AMARAL, Maria José Caldeira do. Eros e Ágape - Minne: O Cúmulo do Amor na Luz fluente da Deidade - Das flieBende Licht der Gottheit- de Mechthild Von Magdeburg. São Paulo, 2008, 207f. Tese (Doutorado) - Programa de Estudos PósGraduados em Ciências da Religião, Pontifícia Universidade Católica de São Paulo. São Paulo.

AMARAl, Maria José Caldeira do, Eros e Agape - Minne: Amar e Desejar Deus na Luz fluente da Deidade de Mechthild de Magdeburg. São Paulo, Editora Reflexão, 2014.

BERDIAEV, Nicolas. Esprit et Liberté. Coletion Théophanie. Paris: Desclée de Brouwer, 1984.

BERDIAEV, Nicolas. Le Noveau Moyen Age. Lausane, Suisse: Editions L’Age de L'Homme, 1985.

CIRLOT, Vitória; GARÍ, Blanca. La Mirada Interior/escritoras místicas e visionárias en la Edad Media. Barcelona: Ediciones Martínez Roca, 1999.

DIAS, Maruzania Soares. O Gozo de Deus. Uma análise lacaniana da experiência Mística na obra de Marguerite Porete. São Paulo, 2010, 229f. Dissertação (Mestrado) Pontifícia Universidade Católica de São Paulo, Programa de Pós-Graduação em Ciências da Religião, São Paulo.

ECKHART, Mestre. Sermões alemães: sermões 1 a 6o. Editora Universitária São Francisco. Petrópolis. Vozes, 2006.

GAGNEBIN, Laurent. Nicolas Berdiaeff ou De la destination créatice de l'homme, Essai sur sa pensée. Lausanne, Suisse: Editions L'Age d'Homme, 1994.

McGINN, Bernard. The foundations of mysticism. The presence of God: A history of Western Christian Mysticism. v. 1. New York: Crossroad, 2003.

McGINN BERNARD. The Flowering of Mysticism: Men and Women in the New Mysticism (1200-1350).The presence of God: A history of Western Christian Mysticism. v. 3. New York: Crossroad, 2003.

MAGDEBURG, Mechthild von. Das flieBende Licht der Gottheit:Nach der Einsiedler Handschrift in Kritischem Vergleichmit der gesamten Überlieferung. München: Hans Neumann; Zürich: Artemis-Verlag, 1990. 
MARGUERITE PORETE. Le Miroir des Âmes Simples et Anéanties.

Introduction, Traductionet notes par Max Huot de Longchamp. Paris: Albin Michel, 1984 .

PORETE, Marguerite. O Espelho das almas simples e aniquiladas e que permanecem somente na vontade e no desejo do Amor. Petrópolis: Vozes, 2008.

VAUCHEZ, Andre. Saints, Prophètes et Visionnaires: Le pouvoirsurnaturel au Moyen Age.Paris: Albin Michel, 1999.

ZUM BRUNN, Émile; DE LIBERA, Alain. Maître Eckhart Méthaphisique du Verbe et Thèologie Négative. Paris: BeauchesneEditeur, 1984. 